\title{
PENGARUH NON PERFORMING LOAN, CAPITAL ADEQUACY RATIO DAN LOAN TO DEPOSIT RATIO TERHADAP PROFITABILITAS
}

\author{
Steven $^{1}$, Silvia $^{2}$, Jholant Bringg Luck Amelia Br Sinaga ${ }^{3}$, Januardin ${ }^{4}$ \\ ${ }^{1,2,3,4}$ Prodi Akuntansi, Fakultas Ekonomi, Universitas Prima Indonesia, Jalan Belanga No. 1 Simp. Ayahanda, \\ Medan, Sumatera Utara, 20118, Indonesia \\ Email : stev_black97@yahoo.co.id
}

\begin{abstract}
This research had purpose to determined the effect of NPL, CAR and LDR on Profitability in banking sector company listing in Indonesia Stock Exchange in years 2013-2017. The population of this research is banking sector company listing in Indonesia Stock Exchange over the period 2013-2017. Techniques used in the sample is Purposive Sampling, so obtained sample of 27 companies. The hypothesis results simultaneously shows NPL, CAR and LDR affect the Profitability in banking sector company listing in Indonesia Stock Exchange in years 2013-2017. The hypothesis results partially shows NPL negative affect and significant the Profitability in banking sector company listing in Indonesia Stock Exchange in years 2013-2017, CAR and LDR positive affect and significant the Profitability in banking sector company listing in Indonesia Stock Exchange in years 2013-2017.

Keywords : NPL, CAR, LDR, Profitability, Banking Sector Company
\end{abstract}

\section{PENDAHULUAN}

Perbankan memanfaatkan kegiatan operasional secara maksimal dengan tujuan untuk meningkatkan profitabilitas. Salah satu indikator yang dipakai untuk menilai profitabilitas bank yaitu ROA, dimana ROA mengukur efektivitas manajemen bank dalam memperoleh profit dengan memanfaatkan keseluruhan aset yang dimilikinya. Penelitian ini menggunakan sektor perbankan yang listing di Bursa Efek Indonesia yang memiliki prospek cerah, karena saat ini kegiatan masyarakat Indonesia sehari-hari tidak dapat terlepas dari jasa perbankan. Jasa perbankan yang dimaksud adalah memberikan pinjaman atau kredit dengan harapan dapat menerima pengembalian yang lebih tinggi.

\section{TINJAUAN PUSTAKA}

Non Performing Loan (NPL). NPL merupakan perbandingan antara kredit macet dengan total kredit, dimana kredit adalah dana pinjaman yang disalurkan oleh bank kepada masyarakat, dan kredit macet adalah pinjaman yang tidak berhasil ditagih oleh bank (Wira, 2011:103). Menurut Taswan (2015:59), formula untuk menghitung rasio ini adalah :

$$
\text { NPL }=\frac{\text { Kredit bermasalah }}{\text { Total Kredit }}
$$

Capital Adequacy Ratio (CAR). Rasio ini merupakan perbandingan antara modal dan simpanan yang berasal dari masyarakat dengan memperhatikan risiko dari aset. Rasio ini merefleksikan cadangan modal dari bank sehingga struktur modal sendiri dari perbankan akan terdiri dari modal inti dan modal pelengkap (Abdullah dan Tantri, 2014:157). Menurut Harmono (2015:116), formula untuk menghitung rasio ini adalah : 


$$
\mathrm{CAR}=\frac{\text { Modal }}{\mathrm{ATMR}} \times 100 \%
$$

Loan to Deposit Ratio (LDR). Rasio ini merupakan perbandingan jumlah kredit yang disalurkan pada masyarakat dengan jumlah dana masyarakat dan modal sendiri yang digunakan (Kasmir, 2012 : 225). Menurut Pandia (2012:128), formula penilaian kesehatan likuiditas bank yang berupa loan to deposit, adalah :

$$
\mathrm{LDR}=\frac{\text { Kredit }}{\mathrm{DPK}} \times 100 \%
$$

Profitabilitas. Rasio ini mencerminkan kemampuan perusahaan untuk menciptakan laba melalui pengelolaan penjualan, kas, modal, jumlah karyawan, jumlah cabang dan operasional lainnya (Harahap, 2013:304). Menurut Sudana (2011:22), rasio ini dihitung dengan formula berikut :

$$
\mathrm{ROA}=\frac{\text { Earning After Tax }}{\text { Total Assets }}
$$

Pengaruh Non Performing Loan terhadap Profitabilitas. Menurut Pandia (2012:173), semakin besar dana yang dapat dihimpun bank, semakin besar kredit yang dapat diberikan dan semakin besar pula kemungkinan memperoleh pendapatan.

Pengaruh Capital Adequacy Ratio terhadap Profitabilitas. Menurut Sudirman (2013:202), di samping penambahan modal dilakukan setelah diketahui rasio kecukupan modal minimum atau CAR di bawah aturan yang ada, penambahan modal juga dilakukan jiak bank tidak dapat menutup biaya operasionalnya. Setiap bank yang asetnya bertambah, menyebabkan aktiva tertimbang menurut resikonya juga bertambah sehingga diperlukan juga peningkatan jumlah modal minimum. Dengan demikian, penambahan modal bank merupakan syarat peningkatan pertumbuhan bank.

Pengaruh Loan to Deposit Ratio terhadap Profitabilitas. Menurut Pandia (2012:182), semakin besar dana yang dapat dihimpun oleh bank, semakin besar kemampuan bank dalam memberikan atau menyalurkan kredit. Ini berarti akan semakin besar jumlah pendapatan (income) bank, namun jumlah pendapatan bank yang besar belum menjamin akan menciptakan laba yang besar, bila seluruh atau sebagian besar dana yang digunakan untuk pemberian kredit tersebut biayanya mahal.

\section{METODE PENELITIAN}

Jenis Penelitian. Jenis penelitian ini ialah penelitian deskriptif. Sifat penelitian ini ialah penelitian explanatory. Penelitian ini menggunakan metode penelitian kuantitatif. Data penelitian ini yang digunakan ialah data sekunder, berupa laporan keuangan perusahaan perbankan yang listing di Bursa Efek Indonesia (BEI).

Populasi dan Sampel. Populasi yang digunakan adalah perusahaan perusahaan perbankan yang listing di BEI dari tahun 2013-2017 yang berjumlah sebanyak 43 perusahaan. Sampel penelitian ini menggunakan teknik purposive sampling. Jadi, jumlah sampel penelitian ini yaitu 27 perusahaan dikalikan dengan 5 tahun penelitian, sehingga jumlah observasi penelitian sebanyak 135.

Teknik Pengumpulan Data. Teknik pengumpulan data dalam penelitian ini dengan menggunakan studi dokumentasi. Pengumpulan data pada penelitian ini berasal dari laporan keuangan perusahaan perbankan yang dipublikasikan oleh BEI periode 2013 sampai dengan 2017. 


\section{HASIL ANALISIS DAN PEMBAHASAN}

\subsection{Hasil Analisis}

Tabel 1 menunjukkan bahwa nilai minimum NPL adalah sebesar 0,037 persen pada PT. Bank Maspion Indonesia, Tbk tahun 2017. Nilai maksimum NPL adalah sebesar 6,390 persen pada PT. Bank Bukopin, Tbk tahun 2017. Nilai rata-rata NPL perusahaan perbankan tahun 2013-2017 adalah 2,03014 persen. Nilai standar deviasi NPL adalah 1,304796. Nilai minimum CAR adalah sebesar 10,252 persen pada PT. Bank Mayapada International, Tbk tahun 2014. Nilai maksimum CAR adalah sebesar 35,119 persen pada PT. Bank Mestika Dharma, Tbk tahun 2016. Nilai rata-rata CAR perusahaan perbankan tahun 2013-2017 adalah 19,21291 persen. Nilai standar deviasi CAR adalah 4,284747.

Tabel 1. Statistik Deskriptif

\begin{tabular}{crrrrr}
\hline & N & Minimum & Maximum & \multicolumn{1}{c}{ Mean } & Std. Deviation \\
\hline NPL & 135 & 0.037 & 6.390 & 2.03014 & 1.304796 \\
CAR & 135 & 10.252 & 35.119 & 19.21291 & 4.284747 \\
LDR & 135 & 41.855 & 164.373 & 87.03658 & 18.150233 \\
ROA & 135 & 0.128 & 3.897 & 1.37482 & 0.814618 \\
Valid N (listwise) & 135 & & & & \\
\hline
\end{tabular}

Sumber : Data olah, 2018

Nilai minimum LDR adalah sebesar 41,855 persen pada PT. Bank Mitraniaga, Tbk tahun 2017. Nilai maksimum LDR adalah sebesar 164,373 persen pada PT. OCBC NISP, Tbk tahun 2015. Nilai rata-rata LDR perusahaan perbankan tahun 2013-2017 adalah 87,03658 persen. Nilai standar deviasi LDR adalah 18,150233. Nilai minimum profitabilitas adalah sebesar 0,128 persen pada PT. Bank Bukopin, Tbk tahun 2017. Nilai maksimum profitabilitas adalah sebesar 3,897 persen pada PT. Bank Mestika Dharma, Tbk tahun 2013. Nilai rata-rata profitabilitas perusahaan perbankan tahun 2013-2017 adalah 1,37482 persen. Nilai standar deviasi profitabilitas adalah 0,814618 .

\section{Hasil Pengujian Asumsi Klasik}

Uji Normalitas. Grafik histogram pada Gambar 1 dapat dilihat garis pada kurva cenderung terlihat simetri sehingga disimpulkan data berdistribusi normal

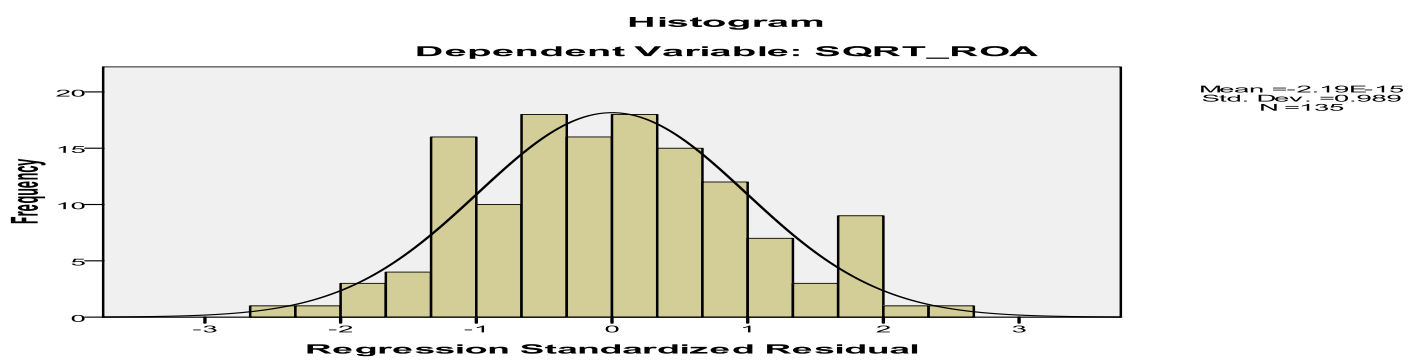

\section{Gambar 1 Uji Normalitas Histogram Setelah Transformasi}

Grafik Normalitas P-P Plot pada Gambar 2 menunjukkan bahwa titik-titik menyebar mendekati garis diagonal sehingga dapat dikatakan data telah berdistribusi normal. Selain analisis grafik, perlu dilakukan analisis statistik untuk memastikan apakah data benar-benar telah terdistribusi normal. 


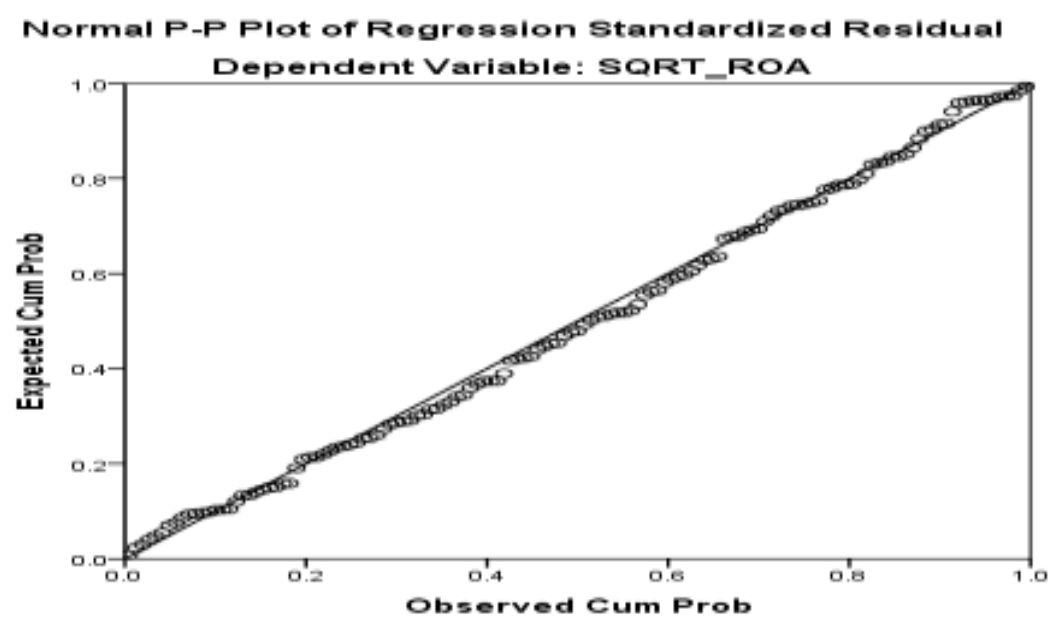

Gambar 2 Uji Normalitas P-P Plot Setelah Transformasi

Tabel 2 menunjukkan bahwa hasil uji normalitas Kolmogorov Smirnov memiliki nilai signifikansi antara 0,200>0,05 sehingga dapat dikatakan bahwa residual error data telah berdistribusi normal.

Tabel 2. Uji normalitas Kolmogorov Smirnov setelah transformasi

\begin{tabular}{|c|c|c|}
\hline & & Unstandardized Residual \\
\hline $\mathrm{N}$ & & 135 \\
\hline \multirow[t]{2}{*}{ Normal Parameters ${ }^{\mathrm{a}, \mathrm{b}}$} & Mean & 0.0000000 \\
\hline & Std. Deviation & 0.31140355 \\
\hline \multirow[t]{3}{*}{ Most Extreme Differences } & Absolute & 0.042 \\
\hline & Positive & 0.042 \\
\hline & Negative & -0.042 \\
\hline Test Statistic & & 0.042 \\
\hline Asymp. Sig. (2-tailed) & & $0.200^{\mathrm{c}, \mathrm{d}}$ \\
\hline
\end{tabular}

a. Test distribution is Normal.

b. Calculated from data.

c. Lilliefors Significance Correction.

d. This is a lower bound of the true significance.

Sumber : Data olah, 2018

Uji Multikolinearitas. Tabel 3 menunjukkan bahwa nilai tolerance variabel NPL, CAR dan LDR setelah transformasi lebih besar dari 0,10 sedangkan nilai VIF variabel NPL, CAR dan LDR setelah transfomasi lebih kecil dari 10, sehingga disimpulkan tidak terjadi korelasi/hubungan antara variabel bebas. 
Tabel 3. Uji multikolinearitas setelah transformasi

\begin{tabular}{lllr} 
& & \multicolumn{2}{c}{ Collinearity Statistics } \\
\cline { 3 - 4 } Model & Tolerance & VIF \\
\hline 1 & (Constant) & & 1.007 \\
& SQRT_NPL & 0.993 & 1.011 \\
& SQRT_CAR & 0.990 & 1.004 \\
& SQRT_LDR & 0.996 &
\end{tabular}

Sumber : Data olah, 2018

Uji Autokorelasi. Tabel 4 menunjukkan bahwa hasil pengujian Durbin-Watson menunjukkan nilai sebesar 1,919; sedangkan dalam tabel DW untuk "k" $=3$ dan $\mathrm{N}=135$. Dengan melihat kriteria pada pedoman Durbin-Watson maka nilai du $<\mathrm{dw}<4$-du atau $1,7645<1,919<2,2355$ maka dari hasil uji Autokorelasi dapat diambil kesimpulan tidak terdapat autokorelasi positif atau negatif.

Tabel 4. Uji autokorelasi setelah transformasi

\begin{tabular}{|c|c|c|c|c|c|}
\hline Model & $\mathbf{R}$ & R Square & $\begin{array}{l}\text { Adjusted R } \\
\text { Square }\end{array}$ & $\begin{array}{l}\text { Std. Error of the } \\
\text { Estimate }\end{array}$ & Durbin-Watson \\
\hline 1 & $0.479^{\mathrm{a}}$ & 0.229 & 0.212 & 0.31495 & 1.919 \\
\hline
\end{tabular}

a. Predictors: (Constant), SQRT_LDR, SQRT_NPL, SQRT_CAR

b. Dependent Variable: SQRT_ROA

Sumber : Data olah, 2018

Uji Heteroskedastisitas. Gambar 3 menunjukkan titik-titik menyebar acak baik diatas maupun dibawah angka 0 di sumbu $Y$, sehingga ditarik kesimpulan yaitu terjadi homoskedastisitas atau tidak terjadi heteroskedastisitas pada model regresi ini.

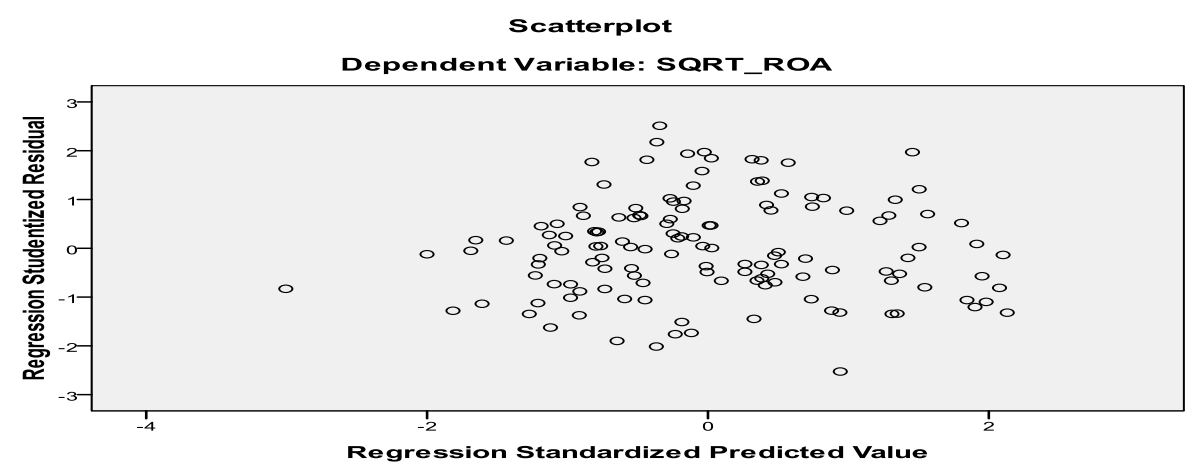

Gambar 3 Uji Heteroskedastisitas Setelah Transformasi

Tabel 5 menunjukkan bahwa hasil uji Glejser setelah transformasi data memiliki nilai signifikan dari 3 variabel independen yaitu NPL, CAR dan LDR lebih besar dari 0,05 dengan demikian hasil dari uji Glejser dapat disimpulkan tidak terjadi masalah heteroskedastisitas. 
Tabel 5. Uji Gletjer setelah transformasi

\begin{tabular}{|c|c|c|c|c|c|c|c|}
\hline \multirow{2}{*}{\multicolumn{2}{|c|}{ Model }} & \multicolumn{2}{|c|}{ Unstandardized Coefficients } & \multirow{2}{*}{\multicolumn{2}{|c|}{$\frac{\text { Standardized Coefficients }}{\text { Beta }}$}} & \multirow[b]{2}{*}{$\mathbf{t}$} & \multirow[b]{2}{*}{ Sig. } \\
\hline & & B & Std. Error & & & & \\
\hline 1 & (Constant) & 0.338 & 0.221 & & & 1.533 & 0.128 \\
\hline & SQRT_NPL & -0.057 & 0.031 & & -0.154 & -1.806 & 0.073 \\
\hline & SQRT_CAR & 0.040 & 0.033 & & 0.105 & 1.229 & 0.221 \\
\hline & SQRT_LDR & -0.020 & 0.016 & & -0.105 & -1.231 & 0.221 \\
\hline
\end{tabular}

a. Dependent Variable: AbsUt2

Sumber : Data olah, 2018

Pengujian hipotesis yang digunakan dalam penelitian adalah dengan menggunakan analisis regresi linier berganda. Persamaan model regresi linier berganda pada penelitian ini dapat diuraikan menjadi :

\section{SQRT_Profitabilitas $=-0,554-0,176$ SQRT_Non Performing Loan + 0,240 SQRT_Capital Adequacy Ratio + 0,093 SQRT_Loan to Deposit Ratio}

Makna dari persamaan regresi linier berganda diatas adalah :

1. Konstanta sebesar $-0,554$ menyatakan bahwa jika NPL, CAR dan LDR bernilai 0 maka profitabilitas senilai $-0,554$.

2. Koefisien regresi NPL sebesar $-0,176$ dan bernilai negatif dinyatakan bahwa setiap kenaikan satu persen NPL mendorong penurunan profitabilitas senilai 0,176 persen.

3. Koefisien regresi CAR sebesar 0,240 dan bernilai positif dinyatakan bahwa setiap kenaikan satu persen CAR mendorong peningkatan profitabilitas senilai 0,240 persen.

4. Koefisien regresi LDR sebesar 0,093 dan bernilai positif dinyatakan bahwa setiap kenaikan satu persen LDR mendorong peningkatan profitabilitas senilai 0,093 persen.

Koefisien Determinasi Hipotesis. Tabel 6 menunjukkan bahwa pengujian koefisien determinasi pada tabel 6 diperoleh nilai Adjusted $R$ square sebesar 0,212, sehingga disimpulkan bahwa variasi variabel profitabilitas yang dapat dijelaskan oleh variabel NPL, CAR dan LDR adalah sebesar 21,2 persen. Sedangkan sisanya sebesar 78,8 persen dijelaskan oleh variabel-variabel independen lainnya diluar penelitian ini.

Tabel 6 Uji Koefisien Determinasi

\begin{tabular}{ccrrr}
\hline Model & R & R Square & \multicolumn{1}{c}{ Adjusted R Square } & \multicolumn{1}{c}{ Std. Error of the Estimate } \\
\hline 1 & $0.479^{\mathrm{a}}$ & 0.229 & 0.212 & 0.31495 \\
\hline
\end{tabular}

a. Predictors: (Constant), SQRT_LDR, SQRT_NPL,

SQRT_CAR

b. Dependent Variable: SQRT_ROA

Sumber : Data olah, 2018

Pengujian Hipotesis Secara Simultan. Tabel 7 menunjukkan bahwa hasil uji signifikansi secara simultan memiliki nilai $F_{\text {hitung }}$ sebesar 12,990. Derajat bebas $1\left(\mathrm{df}_{1}\right)=\mathrm{k}-1=4-1=3$, dan derajat bebas $2\left(\mathrm{df}_{2}\right)=\mathrm{n}-\mathrm{k}=135-4=131$, dimana $\mathrm{n}=$ jumlah sampel, $\mathrm{k}=$ jumlah variabel, nilai $F_{\text {tabel }}$ pada taraf kepercayaan sig 0,05 adalah 2,67. Dengan demikian nilai $F_{\text {hitung }}=12,990$ $>\mathrm{F}_{\text {tabel }}=2,67$ dengan nilai sig 0,000. Maka $\mathrm{H}_{\mathrm{a}}$ diterima yang berarti NPL, CAR dan LDR secara simultan memiliki pengaruh terhadap profitabilitas pada perusahaan sektor perbankan yang listing di BEI pada tahun 2013 - 2017. 


\section{Tabel 7. Uji F}

\begin{tabular}{llrrrrr}
\hline & Model & Sum of Squares & Df & Mean Square & F & \multicolumn{1}{c}{ Sig. } \\
\hline 1 & Regression & 3.866 & 3 & 1.289 & 12.990 & $.000^{\mathrm{b}}$ \\
& Residual & 12.994 & 131 & .099 & & \\
& Total & 16.860 & 134 & & & \\
\hline
\end{tabular}

a. Dependent Variable: SQRT_ROA

b. Predictors: (Constant), SQRT_LDR, SQRT_NPL, SQRT_CAR

Sumber : Data olah, 2018

Pengujian Hipotesis Secara Parsial. Tabel 8 menunjukkan bahwa hasil uji signifikansi secara parsial diperoleh nilai $t_{\text {tabel }}$ untuk probabilitas 0,05 pada derajat bebas $\mathrm{df}=131$ adalah sebesar 1,97824. Dengan demikian hasil dari Uji t dapat dijelaskan sebagai berikut :

1. Dari hasil pengolahan data, dapat diamati nilai $t_{\text {hitung }}$ NPL senilai $-3,199$ dan nilai signifikan 0,002 . Nilai $-t_{\text {hitung }}<-t_{\text {tabel }}$ atau $-3,199<-1,97824$, maka $H_{a}$ diterima artinya NPL memiliki pengaruh negatif signifikan terhadap profitabilitas pada perusahaan sektor perbankan yang listing di BEI pada tahun 2013 - 2017.

2. Dari hasil pengolahan data, dapat diamati nilai $t_{\text {hitung }}$ CAR senilai 4,201 dengan nilai signifikan 0,000. Nilai $t_{\text {hitung }}>t_{\text {tabel }}$ atau 4,201 >1,97824, maka $H_{a}$ diterima artinya CAR memiliki pengaruh positif signifikan terhadap profitabilitas pada perusahaan sektor perbankan yang listing di BEI pada tahun 2013 - 2017.

3. Dari hasil pengolahan data, dapat diamati nilai $t_{\text {hitung }}$ LDR senilai 3,247 dengan nilai signifikan sebesar 0,001. Nilai $t_{\text {hitung }}>t_{\text {tabel }}$ atau 3,247 $>1,97824$, maka $\mathrm{H}_{\mathrm{a}}$ diterima artinya LDR memiliki pengaruh positif signifikan terhadap profitabilitas pada perusahaan sektor perbankan yang listing di BEI pada tahun 2013 - 2017.

Tabel 8. Uji t

\begin{tabular}{|c|c|c|c|c|c|c|c|}
\hline \multirow{2}{*}{\multicolumn{2}{|c|}{ Model }} & \multicolumn{2}{|c|}{ Unstandardized Coefficients } & \multirow{2}{*}{\multicolumn{2}{|c|}{$\begin{array}{c}\text { Standardized Coefficients } \\
\text { Beta }\end{array}$}} & \multirow[b]{2}{*}{$\mathbf{t}$} & \multirow[b]{2}{*}{ Sig. } \\
\hline & & B & Std. Error & & & & \\
\hline 1 & (Constant) & -0.554 & 0.386 & & & -1.437 & 0.153 \\
\hline & SQRT_NPL & -0.176 & 0.055 & & -0.246 & -3.199 & 0.002 \\
\hline & SQRT_CAR & 0.240 & 0.057 & & 0.324 & 4.201 & 0.000 \\
\hline & SQRT_LDR & 0.093 & 0.029 & & 0.250 & 3.247 & 0.001 \\
\hline
\end{tabular}

a. Dependent Variable: SQRT_ROA

Sumber : Data olah, 2018

\subsection{Pembahasan}

Pengaruh Non Performing Loan terhadap Profitabilitas. Dari hasil pengujian data secara parsial diperoleh NPL berpengaruh terhadap profitabilitas pada perusahaan sektor perbankan yang listing di BEI pada tahun $2013-2017$ dengan nilai $-\mathrm{t}_{\text {hitung }}<-\mathrm{t}_{\text {tabel }}$ atau $-3,199$ $<-1,97824$, dengan nilai sig 0,002. Berdasarkan pengujian regresi berganda NPL memiliki pengaruh negatif terhadap profitabilitas, yang berarti kenaikan NPL akan mempengaruhi penurunan profitabilitas.

Pengaruh Capital Adequacy Ratio Ratio terhadap Profitabilitas. Dari hasil pengujian data secara parsial diperoleh CAR berpengaruh terhadap profitabilitas pada perusahaan sektor perbankan yang listing di BEI pada tahun 2013 - 2017 dengan nilai $t_{\text {hitung }}>$ $t_{\text {tabel }}$ atau 4,201 > 1,97824, dengan nilai sig 0,000. Berdasarkan pengujian regresi berganda 
CAR memiliki pengaruh positif terhadap profitabilitas, yang berarti kenaikan CAR akan meningkatkan profitabilitas bank.

Pengaruh Loan to Deposit Ratio terhadap Profitabilitas. Dari hasil pengujian data secara parsial diperoleh LDR berpengaruh terhadap profitabilitas pada perusahaan sektor perbankan yang listing di BEI pada tahun 2013 - 2017 dengan nilai $t_{\text {hitung }}>t_{\text {tabel }}$ atau 3,247 > 1,97824, dengan nilai sig 0,001. Berdasarkan pengujian regresi berganda LDR memiliki pengaruh positif terhadap profitabilitas, yang berarti kenaikan LDR akan meningkatkan profitabilitas bank.

\section{KESIMPULAN DAN SARAN}

\subsection{Kesimpulan}

Berdasarkan analisis data dan hasil penelitian pada perusahaan sektor perbankan yang listing di BEI pada tahun 2013 - 2017, maka dapat disimpulkan bahwa :

1. Secara parsial NPL memiliki pengaruh negatif signifikan terhadap profitabilitas.

2. Secara parsial CAR memiliki pengaruh positif signifikan terhadap profitabilitas.

3. Secara parsial LDR memiliki pengaruh positif signifikan terhadap profitabilitas.

4. Secara simultan NPL, CAR dan LDR memiliki pengaruh signifikan terhadap profitabilitas.

5. Hasil koefisien determinasi Adjusted $\mathrm{R}^{2}$ sebesar 21,2 persen dari variasi variabel profitabilitas yang dapat dijelaskan oleh variabel NPL, CAR dan LDR. Sedangkan sisanya sebesar 78,8 persen dijelaskan oleh variabel-variabel independen lainnya diluar penelitian ini.

\subsection{Saran}

Berdasarkan hasil penelitian yang telah diuraikan di atas, maka saran yang dapat disampaikan peneliti adalah:

1. Bagi investor, disarankan untuk memperhatikan besarnya kredit bermasalah, besarnya modal dan tingkat dana pada suatu bank sebelum menanamkan modalnya karena berdasarkan hasil penelitian menunjukkan besarnya NPL, CAR dan LDR berpengaruh terhadap profitabilitas suatu bank.

2. Bagi perbankan, agar menjaga keseimbangan LDR, jika LDR tidak terkontrol akan berdampak pada nilai NPL yang akan mempengaruhi profitabilitas (kredit yang diberian lebih banyak dengan dana yang diterima kemudian kredit tersebut bermasalah dan menyebabkan laba suatu perusahaan menurun).

3. Bagi peneliti selanjutnya, disarankan untuk menambah variabel lain diluar variabel yang diteliti, seperti Rasio BOPO. Karena berdasarkan hasil koefisien determinasi masih terdapat 78,8 persen faktor lain yang mempengaruhi profitabilitas.

\section{DAFTAR PUSTAKA}

Thamrin \& Francis Tantri. 2014. Bank dan Lembaga Keuangan. Cetakan Ketiga. Jakarta: PT RajaGrafindo Persada.

Bursa Efek Indonesia. 2013-2017. Laporan Keuangan Perusahaan Perbankan. Jakarta.

Chaniago, Junaidi. 2010. Tabel Durbin Watson, Tabel F dan Tabel t. Jambi.

Dendawijaya, Lukman. 2015. Manajemen Perbankan. Cetakan Ketiga. Bogor: Ghalia Indonesia.

Harahap, Sofyan Syafri. 2013. Analisis Kritis atas Laporan Keuangan. Cetakan Kesebelas. Jakarta : PT Raja Grafindo Persada.

Harmono. 2015. Manajemen Keuangan Berbasis Balances Scorecard Pendekatan Teori, Kasus, dan Riset Bisnis. Ed. 1, Cetakan Keempat. Jakarta: Bumi Aksara. 
Hery. 2015. Analisis Laporan Keuangan. Cetakan Pertama. Yogyakarta: CAPS (Center for Academic Publishing Service).

Horne, James C. Van \& John M. Wachowicz, Jr. 2014. Prinsip-Prinsip Manajemen Keuangan. Ed. 13, Jakarta : Salemba Empat.

Ikatan Bankir Indonesia. 2015. Bisnis Kredit Perbankan. Ed. 1, Jakarta: PT Gramedia Pustaka Utama.

Jakarta: PT RajaGrafindo Persada.

Kasmir. 2013. Pengantar Manajemen Keuangan. Cetakan Ketiga Jakarta: Kencana.

Latumaerissa, Julius R. 2014. Manajemen Bank Umum. Jakarta: Mitra Wacana Media.

Muhamad. 2015. Manajemen Dana Bank Syariah. Cetakan Kedua. Jakarta: PT RajaGrafindo Persada.

Murhadi, Werner R. 2015. Analisis Laporan Keuangan : Proyeksi dan Valuasi Saham. Jakarta: Salemba Empat.

Sanusi, Anwar. 2014. Metodologi Penelitian Bisnis. Cetakan Kelima. Jakarta: Mitra Wacana Media.

Subagyo, Ahmad. 2015. Teknik Penyelesaian Kredit Bermasalah. Jakarta: Mitra Wacana Media.

Sudirman, I Wayan. 2013. Manajemen Perbankan: Menuju Bankir Konvensional yang Profesional. Ed. 1, Jakarta: Kencana.

Taswan. 2015. Akuntansi Perbankan. Ed. 3, Yogyakarta: UPP STIM YKPN.

Wahyudiono, Bambang. 2014. Mudah Membaca Laporan Keuangan. Cetakan Pertama. Jakarta: Raih Asa Sukses (Penebar Swadaya Grup).

Wira, Desmond. 2011. Analisis Fundamental Saham. Cetakan Kedua. Exceed. 